\title{
Control of wheat stink bugs (Hemiptera: Pentatomidae) in southern Brazil using the fungus Metarhizium anisopliae
}

\author{
Martin Zanchett Groth ${ }^{1}$, Cristiano Bellée*, Gustavo Zimmer ${ }^{1}$, Maruan Zanchett Groth ${ }^{1}$, Tiago Edu \\ Kaspary $^{3}$, João Roberto Pimentel ${ }^{1}$, Igor Gustavo Oliveira ${ }^{1}$, Vitor Mateus Kolesny' ${ }^{1}$, Paulo Dejalma \\ Zimmer $^{1}$
}

1Universidade Federal de Pelotas, Faculdade de Agronomia Eliseu Maciel, Programa de Pós-Graduação em Ciência e Tecnologia de Sementes. Campus Capão do Leão s/n, 96001-970 Pelotas, Rio Grande do Sul, Brasil ${ }^{2}$ Universidade Federal de Pelotas, Faculdade de Agronomia Eliseu Maciel, Programa de Pós-Graduação em Fitossanidade. Campus Capão do Leão s/n, 96001-970 Pelotas, Rio Grande do Sul, Brasil ${ }^{3}$ Universidade Federal do Rio Grande do Sul, Programa de Pós-Graduação em Fitotecnia, 91540-000 Porto Alegre, Rio Grande do Sul, Brasil

\section{*Corresponding authors: crbelle@gmail.com}

\begin{abstract}
Stink bugs of the species Nezara viridula and Dichelops melacanthus are considered as some of the main insect pests associated with wheat production in Brazil. The use of the entomopathogenic fungus Metarhizium anisopliae might be an alternative for the management of these insects with chemical insecticides. Thus, the aim of this study was to evaluate and ascertain the pathogenicity of different isolates of $M$. anisopliae on $N$. viridula and D. melacanthus adults under laboratory and greenhouse conditions. In the laboratory, the fungal isolates 05RA, 11RA, 08RA, and 02RA, which were collected in the field from adults of $N$. viridula and D. melacanthus infected with $M$. anisopliae, were highly pathogenic, leading to $100 \%$ mortality in adults of $N$. viridula and $D$. melacanthus at 8 days after application (DAA). However, the isolate 08RA presented higher pathogenicity in a shorter period of time for $N$. viridula (mean mortality time "MMT" $=2.8$ days) and D. melacanthus (MMT $=4.0$ days) than the remaining isolates. At the greenhouse, the isolate 08RA led to a mortality of $44.9 \%(N$. viridula) and $35.7 \%$ (D. melacanthus) at eight DAA; however, the mortality was $100 \%$ for both species at 14 DAA, with an MMT of 8 and 10 days for $N$. viridula and D. melacanthus, respectively. The fungus $M$. anisopliae constitutes a promising alternative agent to control the growth of adult populations of $N$. viridula and $D$. melacanthus in wheat cultures.
\end{abstract}

Keywords: Hemiptera, Nezara viridula, Dichelops melacanthus, biological control, Ascomycetes, Triticum aestivum, mortality, pathogenicity.

Abbreviations: ANOVA_analysis of variance; BOD_biochemical oxygen demand; DAA _days after application; MMT_mean mortality time; PDA_ potato dextrose agar.

Introduction

A wide range of stink bug species (Hemiptera: Pentatomidae) are considered pests of Brazilian crops, including soybean, corn, and wheat. The establishment of new production programs in the Brazilian agricultural regions of "CentroOeste" (Midwest) and "Sul" (Southern), where soybean is cultivated in the summer and wheat in the winter, along with the expansion of no-till seeding has triggered the population growth of stink bug species in wheat crops (Chocorosqui and Panizzi, 2004). Wheat is highly susceptible to damage in all its developmental phases; however, greater losses occur during seed formation at the grain milk stage (Chocorosqui and Panizzi, 2004). Two of the stink bug species are particularly harmful to wheat: the southern green stink bug Nezara viridula (Linnaeus, 1758) and the green-belly stink bug Dichelops melacanthus (Dallas, 1851).

The damage caused by D. melacanthus is more accented during wheat establishment (vegetative phase), and it is exerted through the injection of saliva during feeding, causing subsequent transverse marks, necrosis, and rolling and/or desiccation of leave portions. Another important consequence is abnormal tiller formation leading to a symptom known as "cebolinha" (chive) (Gomez and Ávila 2004; Manfredi-Coimbra et al., 2005). On the other hand, the damage by $N$. viridula is more pronounced during the reproductive phase (ear development) and may lead to ear drying and plant death (Manfredi-Coimba et al., 2005).

Insecticides, applied via seed dressing or aerial spraying, are the most employed control methods of insect pests in wheat (Nuyttens et al., 2013). However, because insecticide usage may promote the rise of insecticide-resistant stink bug populations in Brazil (Sosa-Gomez and Silva, 2010; Lopez et al., 2012) and it may also increase the risk of food contamination due to the presence of chemical residues in grains (Tibola et al., 2009), studies seeking to provide new alternatives of insect pests management are required.

In this context, biological control with the use of the entomopathogenic fungus Metarhizium anisopliae (Metschnikoff) Sorokin (Ascomycetes: Hypocreales) might 
be a viable strategy for the management and control of $N$. viridula and $D$. melacanthus in wheat. Due to the wide distribution of $M$. anisopliae in the ecosystem (soil) and its ability to infect a great number of insects, the use of this fungus as an alternative biological pest management tool has been suggested (Sung et al., 2007; Sandhu et al., 2012). Furthermore, natural infestations of $M$. anisopliae in stink bug species were reported (Xavier and Ávila 2006; Barbosa et al., 2015); this fungus was employed to control the sugarcane spittlebug Mahanarva posticata (Stal, 1855) (Hemiptera: Cercopidae) (Loureiro et al., 2012) and other pest stink bug species (Martins et al., 2004; Xavier and Ávila, 2006; França et al., 2006; Rampelotti et al., 2007).

Due to evidence of a high pathogenicity of $M$. anisopliae in insects and its suitability to be cultured in the laboratory (Rohde et al., 2006), the identification of suitable isolates of this fungus to control $N$. viridula and $D$. melacanthus might provide subsidies for the biological management of these pests in wheat. Thus, the aim of this study was to evaluate the pathogenicity of $M$. anisopliae isolates in $N$. viridula and $D$. melacanthus under laboratory and greenhouse conditions.

\section{Results}

Pathogenicity of isolates of M. anisopliae on N. viridula and D. melacanthus in the laboratory

Under laboratory conditions, the successful germination of conidia, isolated from dead insects and subsequently cultured in potato dextrose agar (PDA), confirmed that the adults of $N$. viridula and D. melacanthus were highly susceptible to the fungus $M$. anisopliae and that viable conidia can be obtained from $100 \%$ of the collected insects. Furthermore, a significant interaction between time and exposure of the insects $N$. viridula and $D$. melacanthus to the fungus $M$. anisopliae was detected. An adult insect mortality of $100 \%$ was observed at eight days after application (DAA) (Table 1). The $M$. anisopliae isolate 08RA was the most pathogenic of all four evaluated isolates $(\mathrm{F}=7.584$; d.f. $=19,4 ; \mathrm{P}<$ 0.0001 ), leading to a maximum mortality in $N$. viridula at 2.82 days (Figure 1) and in D. melacanthus at 3.93 days (Figure 2)., which was significantly different ( $F=7.584$; d.f. $=19,4$; $\mathrm{P}<0.0001)$ from the remaining isolates evaluated 05RA and 11RA (3.0 days) and 02RA (4.95 days) for $N$. viridula (Figure 1) and 05RA (3.59 days), 11RA (3.37 days) and 02RA (8.0 days) for D. melacanthus (Figure 2) which were statistically different for the control where mortality was between 15 to $20 \%$ (Table 2). Due to its greater pathogenicity in a shorter period of time, the isolate 08RA was selected for bioassays under greenhouse conditions.

\section{Efficacy of M. anisopliae under greenhouse conditions}

In the bioassays at greenhouse it was verified a significant interaction between the application of the isolate (08RA) of the fungus $M$. anisopliae and the time of exposure for adults of $N$. viridula $(\mathrm{F}=0.896 ; \mathrm{df} .=19.1 ; \mathrm{p}<0.001)$ and of $D$. melacanthus $(\mathrm{F}=0.026 ;$ d.f. $=19, .1 ; \mathrm{p}<0.001) \quad$ (Table 2). Through orthogonal polynomials, was verified that at the eight DAA, there was a point of maximum for mortality as a function of the mean mortality time (MMT) for $N$. viridula (58\% of mortality) and for D. melacanthus (50\% of mortality) (Figure 3). However, at the 14 DAA, the mortality was $100 \%$ for both species studied (Table 2), statistically differing $(\mathrm{F}=0.125 ;$ d.f. $=19.1 ; \mathrm{p}<0.001)$ from the control which was exactly $16.7 \%$ in both insect species $(F=0.125$; d.f. $=19.1 ; \mathrm{p}<0.001)($ Table 2$)$.

\section{Discussion}

The high infectivity of the tested $M$. anisopliae isolates in adults of the insect species $N$. viridula and D. melacanthus was confirmed by the presence of hardened bodies and abundant spores. Furthermore, the development of a mycelial mass (silver to white colored) and the production of conidia (green colored) over the insects' bodies on post-mortem observations confirmed that insect mortality was due to the application of the fungus M. anisopliae (Roy and Cottrell, 2008). However, after the application of the fungus $M$. anisopliae, a direct relationship between the time of application and mortality of the two stink bug species was observed; almost all fungal isolates had daily mortality peaks between the third and fifth DAA. The efficiency of biocontrol with $M$. anisopliae has been previously reported, namely this fungus has been a particularly efficient in controlling the growth of adults of brown root stink bug Scaptocoris carvalhoi Becker (Hemiptera: Cydnidae) (Xavier and Ávila, 2006) and sugarcane spittlebug Mahanarva fimbriolata (Stal, 1854) (Hemiptera: Cercopidae) in sugarcane (Carvalho et al., 2011).

Considering the routes of exposure of adults of $N$. viridula and D. melacanthus, topping application (laboratory) provided a greater rate of infection and mortality in a shorter period of time. The greaterlarger time span that the fungus required to reach its maximum pathogenicity in adult stink bugs of both species in the greenhouse setup might be related to the method of inoculation and the environmental conditions. In the laboratory, the fungus $M$. anisopliae was applied directly on the pronotum of the insects, which were posteriorly placed in plastic boxes and stored under controlled temperature and humidity, creating an adequate microclimate for the development, multiplication, and penetration of the spores in the body. In contrast, during the bioassays under greenhouse conditions, the insects were sprayed with an aqueous conidial suspension. Such a procedure may have resulted in a less effective contact of the fungal solution with the insects body, thus increasing the time required for spore penetration and colony establishment (Boucias et al., 1988; Alexandre et al., 2006). It is important to highlight that the environmental conditions at the greenhouse may have interfered directly in the development of the fungus as well as the pathogenicity of entomopathogenic fungi directly depends on air temperature and humidity. In addition, to favor the spread of an entomopathogenic fungus, the insect population size must be large. These factors may have delayed the growth of $M$. anisopliae, making the process of infectivity slower than that in laboratory bioassays.

Because of the high mortality elicited by the isolate 08RA within a short period of time in both stink bug species, $N$. viridula and D. melacanthus, and because of its capacity for rapid multiplication in the laboratory (Leite et al., 2003), the use of this isolate may be a promising alternative for the management of these insects during wheat production. Besides allowing a decrease in the application of chemical insecticides, the use of $M$. anisopliae on pest management may provoke the horizontal spread of conidia in the soil for longer periods. This would, in turn, increase the concentration of this entomopathogenic fungus in the environment and facilitate a more effective insect control with the course of time (Almeida et al., 2007; Barboza et al., 2011).

The microbial control of $N$. viridula and D. melacanthus in wheat through the use of $M$. anisopliae in addition to reducing 
Table 1. Mean number of live insects $(\mathrm{N} \pm \mathrm{SE})$ and cumulative mortality $(\% \mathrm{M})$ of adults of the insect species Nezara viridula and Dichelops melacantus exposed to different isolates of Metarhizium anisopliae in the laboratory.

\begin{tabular}{|c|c|c|c|c|c|c|c|c|}
\hline \multirow{3}{*}{ Isolate } & \multicolumn{8}{|c|}{ Days After Application (DAA) } \\
\hline & \multicolumn{2}{|l|}{2} & \multicolumn{2}{|l|}{4} & \multicolumn{2}{|l|}{6} & \multicolumn{2}{|l|}{8} \\
\hline & $\mathrm{N} \pm \mathrm{SE}^{1}$ & $\% \mathrm{M}^{2}$ & $\mathrm{~N} \pm \mathrm{SE}^{1}$ & $\% \mathrm{M}^{2}$ & $\mathrm{~N} \pm \mathrm{SE}^{1}$ & $\% \mathrm{M}^{2}$ & $\mathrm{~N} \pm \mathrm{SE}^{1}$ & $\% \mathrm{M}^{2}$ \\
\hline \multicolumn{9}{|c|}{ Nezara viridula } \\
\hline 08RA & $5.10 \pm 0.03 \mathrm{~A}$ & 15.0 & $0.75 \pm 0.03 \mathrm{~A}$ & 87.2 & $0.00 \pm 0.0 \mathrm{~A}$ & 100.0 & - & - \\
\hline 05RA & $5.50 \pm 0.04 \mathrm{~A}$ & 8.3 & $2.20 \pm 0.03 \mathrm{~B}$ & 62.7 & $0.45 \pm 0.03 \mathrm{~B}$ & 91.8 & $0.00 \pm 0.00 \mathrm{~A}$ & 100 \\
\hline 11RA & $4.70 \pm 0.03 \mathrm{~A}$ & 21.6 & $2.11 \pm 0.04 \mathrm{~B}$ & 64.4 & $0.50 \pm 0.03 \mathrm{~B}$ & 90.9 & $0.00 \pm 0.00 \mathrm{~A}$ & 100 \\
\hline 02RA & $5.10 \pm 0.04 \mathrm{~A}$ & 15.0 & $3.15 \pm 0.04 \mathrm{~B}$ & 46.6 & $1.15 \pm 0.04 \mathrm{C}$ & 79.1 & $0.00 \pm 0.00 \mathrm{~A}$ & 100 \\
\hline Control & $6.00 \pm 0.01 \mathrm{~B}$ & 0.0 & $5.90 \pm 0.01 \mathrm{C}$ & 1.6 & $5.50 \pm 0.01 \mathrm{D}$ & 8.3 & $5.1 \pm 0.02 \mathrm{~B}$ & 15 \\
\hline \multicolumn{9}{|c|}{ Dichelops melacanthus } \\
\hline 08RA & $4.85 \pm 0.04 \mathrm{~A}$ & 17.1 & $0.85 \pm 0.031 \mathrm{~A}$ & 84.8 & $0.00 \pm 0.0 \mathrm{~A}$ & 100.0 & - & - \\
\hline 05RA & $5.50 \pm 0.04 \mathrm{~A}$ & 5.9 & $3.15 \pm 0.028 \mathrm{~B}$ & 44.6 & $0.95 \pm 0.02 \mathrm{~B}$ & 82.2 & $0.00 \pm 0.0 \mathrm{~B}$ & 100.0 \\
\hline $11 \mathrm{RA}$ & $5.51 \pm 0.05 \mathrm{~A}$ & 5.9 & $3.15 \pm 0.034 \mathrm{~B}$ & 44.6 & $1.35 \pm 0.02 \mathrm{~B}$ & 74.8 & $0.00 \pm 0.0 \mathrm{~B}$ & 100.0 \\
\hline 02RA & $5.65 \pm 0.03 \mathrm{~A}$ & 3.4 & $4.00 \pm 0.045 \mathrm{~B}$ & 28.6 & $2.15 \pm 0.03 \mathrm{~B}$ & 59.8 & $0.00 \pm 0.0 \mathrm{~B}$ & 100.0 \\
\hline Control & $5.85 \pm 0.01 \mathrm{~A}$ & 0.7 & $5.65 \pm 0.011 \mathrm{C}$ & 6.7 & $5.35 \pm 0.02 \mathrm{C}$ & 10.8 & $4.80 \pm 0.02 \mathrm{C}$ & 20.0 \\
\hline
\end{tabular}

${ }^{1}$ Means followed by the same upper case letters in the columns are not significantly different by Tukey test (P $\left.\leq 0.05\right)$. ${ }^{2}$ Mortality corrected according to Henderson and Tilton (1955).
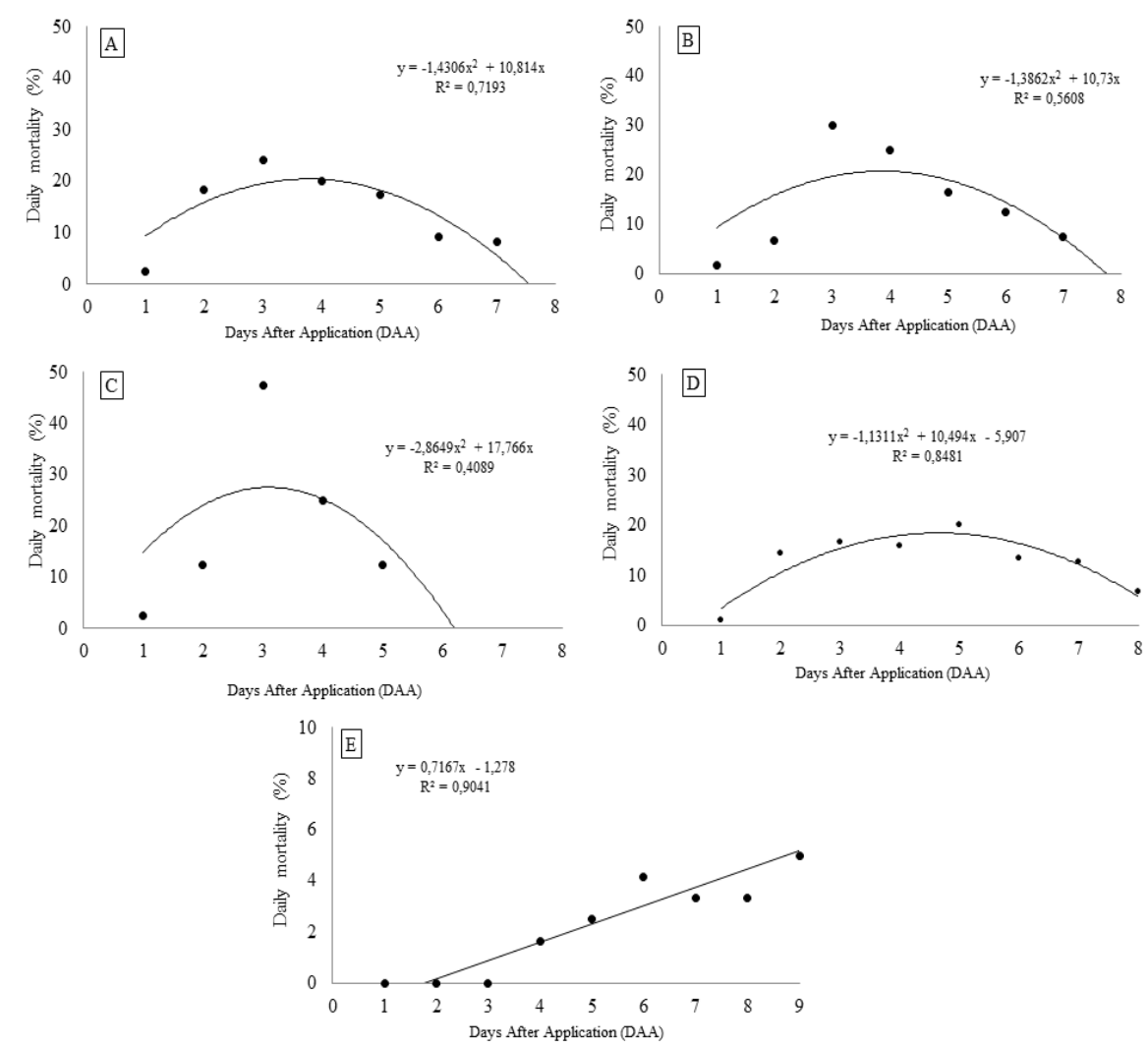

Fig 1. Daily mortality of the insect Nezara viridula after the application of different isolates of the fungus Metarhizium anisopliae in the laboratory. (A) isolate 08RA; (B) isolate 05RA; (C) isolate 11RA; (D) isolate 02RA; and (E) Control. 
Table 2. Mean number of live insects $(\mathrm{N} \pm \mathrm{SE})$ and cumulative mortality $(\% \mathrm{M})$ of adults of the insect species Nezara viridula and Dichelops melacantus exposed to the isolate 08RA of Metarhizium anisopliae in a greenhouse setup.

\begin{tabular}{|c|c|c|c|c|c|c|c|c|c|c|c|c|c|c|}
\hline \multirow{3}{*}{ Treatment } & \multicolumn{14}{|c|}{ Days After Application (DAA) } \\
\hline & \multicolumn{2}{|l|}{2} & \multicolumn{2}{|l|}{4} & \multicolumn{2}{|l|}{6} & \multicolumn{2}{|l|}{8} & \multicolumn{2}{|l|}{10} & \multicolumn{2}{|l|}{12} & \multicolumn{2}{|l|}{14} \\
\hline & $\mathrm{N} \pm \mathrm{SE}^{1}$ & $\% \mathrm{M}^{2}$ & $\mathrm{~N} \pm \mathrm{SE}^{1}$ & $\% \mathrm{M}^{2}$ & $\mathrm{~N} \pm \mathrm{SE}^{1}$ & $\% \mathrm{M}^{2}$ & $\mathrm{~N} \pm \mathrm{SE}^{1}$ & $\% \mathrm{M}^{2}$ & $\mathrm{~N} \pm \mathrm{SE}^{1}$ & $\% \mathrm{M}^{2}$ & $\mathrm{~N} \pm \mathrm{SE}^{1}$ & $\% \mathrm{M}^{2}$ & $\mathrm{~N} \pm \mathrm{SE}^{1}$ & $\% \mathrm{M}^{2}$ \\
\hline \multicolumn{15}{|c|}{ Nezara viridula } \\
\hline 08RA & $5.80 \pm 0.03 \mathrm{~A}$ & 1.7 & $5.30 \pm 0.02 \mathrm{~A}$ & 8.6 & $4.35 \pm 0.03 \mathrm{~A}$ & 23.9 & $3.0 \pm 0.02 \mathrm{~A}$ & 44.9 & $1.7 \pm 0.04 \mathrm{~A}$ & 66.3 & $0.8 \pm 0.03 \mathrm{~A}$ & 84.0 & $0.0 \pm 0.00 \mathrm{~A}$ & 100.0 \\
\hline Control & $5.90 \pm 0.01 \mathrm{~A}$ & 1.7 & $5.80 \pm 0.01 \mathrm{~A}$ & 3.3 & $5.65 \pm 0.01 \mathrm{~B}$ & 5.8 & $5.2 \pm 0.01 \mathrm{~B}$ & 9.2 & $5.2 \pm 0.01 \mathrm{~B}$ & 9.2 & $5.0 \pm 0.01 \mathrm{~B}$ & 16.7 & $5.0 \pm 0.01 \mathrm{~B}$ & 16.7 \\
\hline \multicolumn{15}{|c|}{ Dichelops melacantus } \\
\hline $08 \mathrm{RA}$ & $5.80 \pm 0.03 \mathrm{~A}$ & 1.7 & $5.45 \pm 0.03 \mathrm{~A}$ & 5.2 & $4.60 \pm 0.04 \mathrm{~A}$ & 20.3 & $3.5 \pm 0.03 \mathrm{~A}$ & 35.7 & $2.4 \pm 0.04 \mathrm{~A}$ & 55.1 & $\begin{array}{l}1.8 \pm 0.02 \\
\mathrm{~A}\end{array}$ & 84.0 & $\begin{array}{l}0.0 \pm 0.00 \\
\text { A }\end{array}$ & 100.0 \\
\hline Control & $5.90 \pm 0.02 \mathrm{~A}$ & 1.6 & $5.75 \pm 0.02 \mathrm{~A}$ & 4.2 & $5.20 \pm 0.02 \mathrm{~B}$ & 13.3 & $5.2 \pm 0.01 \mathrm{~B}$ & 13.3 & $5.2 \pm 0.02 \mathrm{~B}$ & 13.3 & $5.0 \pm 0.01 \mathrm{~B}$ & 16.7 & $5.0 \pm 0.01 \mathrm{~B}$ & 16.7 \\
\hline
\end{tabular}

${ }^{\mathrm{T}}$ Means followed by the same upper case letters in the columns are not signific antly different by Tukey test ( $\left.\mathrm{P} \leq 0.05\right)$. ${ }^{2}$ Mortality corrected according to Henderson and Tilton (1955).
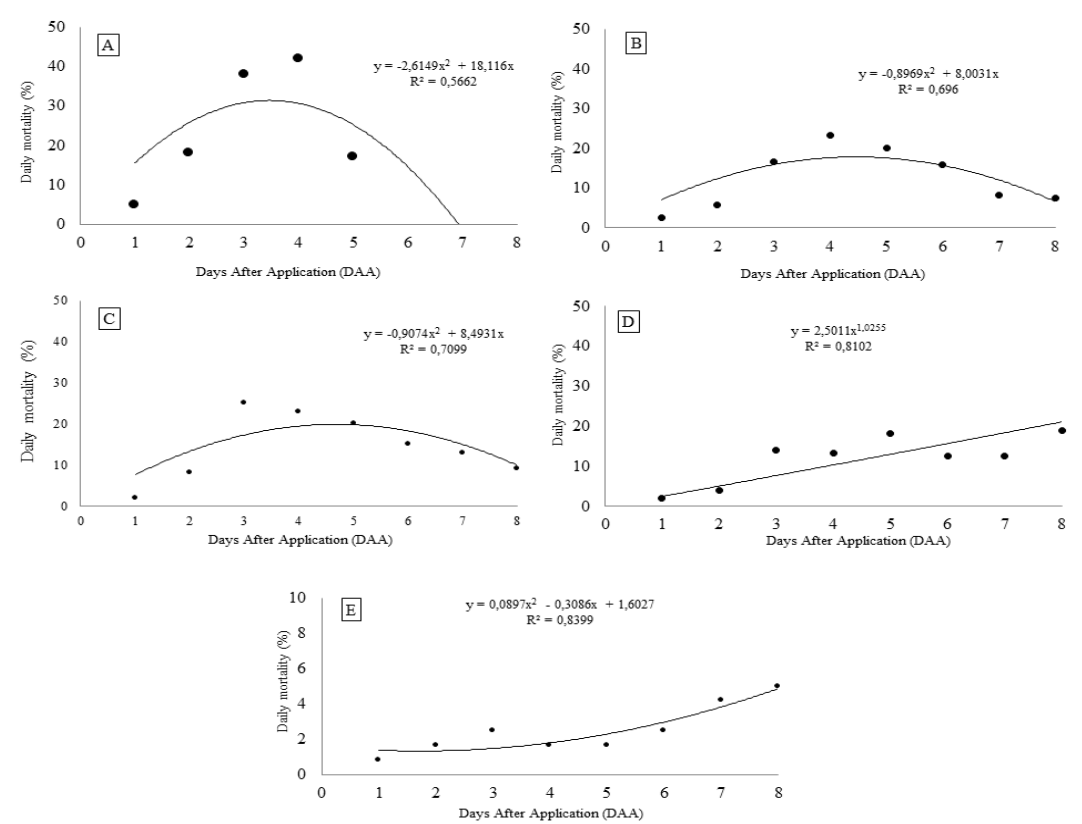

Fig 2. Daily mortality of the insect Dichelops melacantus after the application of different isolates of the fungus Metarhizium anisopliae in the laboratory. (A) isolate 08RA; (B) isolate 05RA; (C) isolate 11RA; (D) isolate 02RA; and (E) control. 

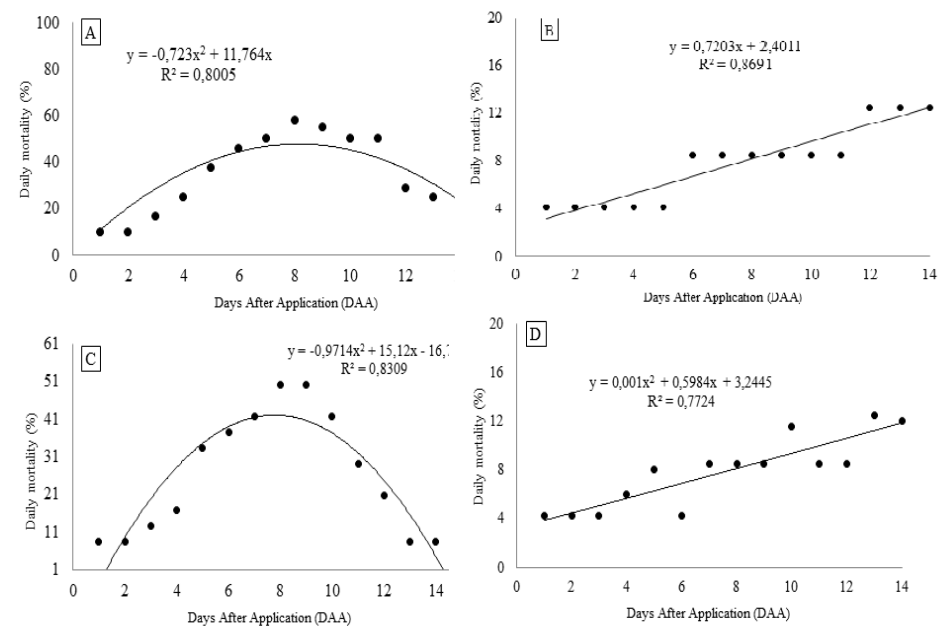

Fig 3. Daily mortality of the insect Nezara viridula under (A) treatment and (B) Control and of the insect Dichelops melacantus under (C) treatment and (D) Control after the application of the fungus Metarhizium anisopliae (isolate 08RA) in a greenhouse setup.

production costs and lowering environmental impacts could also be effective to control other wheat pests, such as the wheat grain beetle Anisoplia austriaca (Herbst, 1783) (Roberts and Leger, 2004).

\section{Materials and Methods}

All experiments were performed in the Laboratory of Microbiology of the Universidade do Oeste de Santa Catarina (University of the West of Santa Catarina), São Miguel do Oeste - SC, Brazil, during the period of May to October of 2013, and the procedures were performed under controlled environmental conditions.

\section{Insect material and isolates}

The isolates of the entomopathogenic fungus $M$. anisopliae (isolates 05RA, 11RA, 08RA, and 02RA) used in the bioassays were collected and selected from $N$. viridula and $D$. melacanthus stink bugs, which were found dead and infested by the fungus in wheat fields. In the laboratory, the isolates were cultured in Petri dishes with PDA medium (potato + dextrose + agar + chloramphenicol) (Pitt and Hockig, 1997) and maintained under controlled conditions $\left(25^{\circ} \mathrm{C}\right)$, according to the methodology proposed by Alves et al. (1998). The identification of the isolates was performed based on the characteristics of the colonies and morphometry of the conidia according to Yip et al. (1992). All adult stink bugs of $N$. viridula and $D$. melacanthus used in the remaining steps of the experiment were reared in the laboratory following the methodology proposed by Corrêa-Ferreira (1985).

\section{Plant material}

At the greenhouse, wheat seeds cv. "TBIO Alvorada" were sown at a rate of 10 seeds/pot in 8-L plastic pots containing soil and organic (vegetal) substrate in a 1:1 ratio. Seven days after sowing, thinning was performed by maintaining five plants per pot and then, for the remainder of the experiment, crop management was conducted according to the recommendations for wheat crops in the State of Santa Catarina (CBPTT 2012).

\section{Pathogenicity of the isolates of M. anisopliae on N. viridula and D. melacanthus in the laboratory}

The efficiency and the pathogenicity of the isolates 05RA, 11RA, 08RA, and 02RA of the entomopathogenic fungus $M$. anisopliae on $N$. viridula and D. melacanthus were evaluated using topically applied bioassays on adult insects. First, the isolates were replicated in Petri dishes containing PDA medium and used after 15 days of growth. The experimental units consisted of plastic boxes Gerbox ${ }^{\mathrm{TM}}(11.0 \times 11.0 \times 3.5$ $\mathrm{cm})$. Box lids were disinfected with $1 \%$ sodium hypochlorite, the bottom was lined with filter paper, and then entire boxes were placed in an ultraviolet chamber for $15 \mathrm{~min}$. Before the release of stink bugs to the interior of the boxes, the adults were disinfested using a solution of $1 \%$ sodium hypochlorite for approximately $5 \mathrm{~s}$, and posteriorly, they were treated with distilled water to eliminate any possible contaminants. Then, each experimental unit received six 14-day-old adults of $N$. viridula or D. melacanthus and a bean pod of Phaseolus vulgaris (Linnaeus, 1753) as feeding substrates. The pods were replaced every 2 days, and moisture was reestablished when necessary. Finally, $24 \mathrm{~h}$ after the release of the insects into the boxes, $1 \mathrm{~mL}$ of the homogenized solution of each isolate (05RA, 11RA, 08RA, and 02RA) was applied on the pronotum of the insects, with the assistance of a $1000-\mu \mathrm{L}$ micropipette. The applied volume exposed each insect to approximately 500,000 conidia.

After applying the conidial suspension, the insects were placed in a climatized chamber at a temperature of $25^{\circ} \mathrm{C}$. The experimental design was completely randomized and included four treatments (isolates) and a control (water). Each treatment consisted of 20 repetitions, with each repetition being one Gerbox box for each of the insect species. The evaluated variables were mortality at zero, two, four, six, and eight DAA and the MMT during a period of 8 days.

To confirm the cause of mortality of adults under each fungal isolate, groups of three dead insects, per species and repetition, were placed into sterilized Petri dishes containing PDA (as previously described). These Petri dishes were sealed at the top using Parafilm $M^{\circledR}$ and then placed in a biochemical oxygen demand incubator for a period of 5 days. The fungal cultures were evaluated under a stereo 
microscope $(40 \mathrm{x})$, and those in which germinated conidia could be seen were considered as positive.

\section{Efficacy of M. anisopliae under greenhouse conditions}

To determine the pathogenicity of the fungus M. anisopliae in adults of $N$. viridula and D. melacanthus in a greenhouse setup, the fungal isolate 08RA was used due to its greater efficiency in inducing mortality in both insect species in the laboratory in a shorter period of time. Therefore, the isolate 08RA was multiplied in PDA medium, as already mentioned. Wheat plants at the boot stage were infested, per pot, with six adults of $N$. viridula or $D$. melacanthus. After 2 days, a conidial aqueous suspension of the $M$. anisopliae isolate 08RA at a concentration of $10^{8}$ conidia/mL was sprayed on each pot with the assistance of a hand sprayer (PCP 424,00, Guarany ${ }^{\mathrm{TM}}$ ) under a pressure of $10 \mathrm{lb} / \mathrm{in}^{2}$ and a volume of $20.0 \mathrm{~mL}$. To prevent the escape of insects, plastic pots were accommodated into cages fabricated with "voile" fabric $(70 \times$ $40 \times 40 \mathrm{~cm}$ ), which were suspended by frames of galvanized wires. In this design, the control consisted of wheat plants infested with adults of $N$. viridula or D. melacanthus, which were sprayed with water. The variables evaluated were mortality at 0-14 DAA, with an interval of 2 days. Additionally, MMTs were also determined. This experimental design was completely randomized, including 20 repetitions per treatment; one repetition consisted of a plastic pot with five wheat plants and six adults of $N$. viridula or D. melacanthus. The confirmation that the mortality of adults of the two insect species was due to the $M$. anisopliae isolate 08RA was performed, allowing the germination of the fungus following the protocol described in the preceding section.

\section{Statistical analysis}

All data were tested for normality with Bartlett ShapiroWilk's method. Then, all observations were "square-root + 0.1 " transformed and subjected to analyses of variance (ANOVA). When an F-statistic was significant, a post hoc Tukey test at the 5\% significance level $(\mathrm{p}<0.05)$ was performed (Cruz, 2013).

\section{Conclusion}

The fungus anisopliae constitutes a promising alternative agent to control the growth of adult populations of $N$. viridula and $D$. melacanthus in wheat cultures.

\section{References}

Alexandre TM, Alves LFA, Neves PMOJ, Alves SB (2006) Efeito da temperatura e substrato sobre Beauveria bassiana e Metarhizium anisopliae e sua relação no controle do cascudinho (Alphitobius diaperinus) (Panzer) (Coleoptera: Tenebrionidae). Neotrop Entomol. 35: 75-82.

Almeida JEM, Batista Filho A, Costa EAD (2007) Efeito de adjuvantes em associação com Thiamethoxam 250 WG e Metarhizium anisopliae (Metsch.) Sorokin no controle de cigarrinha-da-raiz da cana-de- -açúcar Mahanarva fimbriolata (Stal, 1854) (Hemiptera: Cercopidae). Arq Inst Biol. 74:135-140.

Alves SB, Almeida JEM, Moino Jr A, Alves LFA (1998) Técnicas de laboratório, In Alves S.B (ed.), Controle microbiano de insetos. Piracicaba, FEALQ, p.637-711pp.

Barbosa RH, Kassab SO, Fonseca PRB, Rossoni C, Silva AS (2015) Associação de Metarhizium anisopliae (Hyp.:
Clavicipitaceae) e thiamethoxam para o controle da cigarrinha-das-raízes em cana-de-açúcar. Ensaios e Cienc. $15: 41-51$.

Boucias DG, Pendland JC, Latge JP (1988) Nonspecific factors involved in attachment of entomopathogenic deuteromycetes to host insect cuticle. Appl Environ Microbiol. 54: 1795-1805.

Carvalho LWT, Broglio-Micheletti SMF, Carvalho LHT, Dias NS, Girón-Pérez K (2011) Incidencia de Mahanarva fimbriolata después de aplicaciones de Metarhizium anisopliaee imidacloprid en caña-de-azúcar. Rev Caatinga. 24:20-26.

Chocorosqui VR, Panizzi AR (2014) Impact of cultivation systems on Dichelops melacanthus (Dallas) (Heteroptera: Pentatomidae) populations and damage and its chemical control on wheat. Neotrop Entomol. 33:487-492.

Comissão Brasileira de Pesquisa de Trigo e Triticale (CBPTT) (2013) Informações técnicas para trigo e triticale - safra 2013. Londrina: Fundação Meridional, 200 pp.

Corrêa-Ferreira BS (1985) Criação massal do percevejo verde Nezara viridula (L.). Londrina: EMBRAPA - Centro Nacional de Pesquisa de Soja. 16 p.

Cruz CD (2013) GENES - a software package for analysis in experimental statistics and quantitative genetics. Acta Sci Agron. 35:271276.

França IWB, Marques EJ, Torres JB, Oliveira JV (2006) Efeitos de Metarhizium anisopliae (Metsch.) Sorok. E Beauveria bassiana (Bals.) Vuill. sobre o percevejo predador Podisus nigrispinus Dallas (Heteroptera: Pentatomidae). Neotrop Entomol. 35:349-356.

Gomez SA, Ávila CJ (2004) Ameaça verde. Cult Gran Cult. 5:28-29.

Henderson CF, Tilton EW (1955) Tests with acaricides against the brow wheat mite. J Econ Entomol. 48:157-161.

Leite LG, Batista Filho A, Almeida JEM, Alves SB (2003) Processos de produção. In Leite Leite LG, Batista Filho A, Almeida JEM, Alves SB. Produção de fungos entomopatogênicos. Ribeirão Preto, Alexandre de Sene Pinto. 33-44 pp.

Lopez JDJR, Latheef M, Ree M (2012) Toxicity by glassvial bioassay of selected pyrethroid and organophosphate insecticides to adult brown stink bugs (Hemiptera: Pentatomidae) from Central Texas Southwest. Entomol. 37:39-46.

Loureiro ES, Batista Filho A, Mendes JM, Pessoa LGA (2012) Eficiência de isolados de Metarhizium anisopliae (metsch.) sorok. no controle da cigarrinha-da-raiz da canade-açúcar, Mahanarva fimbriolata (stal, 1854) (Hemiptera: Cercopidae), em condições de campo. Arq Inst Biol. 79:4753.

Manfredi-Coimbra S, Silva JJ, Chocorosqui VR, Panizzi AR (2005) Danos do percevejo barriga-verde Dichelops melacanthus (Dallas) (Heteroptera: Pentatomidae) em trigo. Cienc Rural. 35:1243-1247.

Martins JFS, Botton M, Carbonari JJ, Quintela ED (2004) Eficiência de Metarhizium anisopliae no controle do percevejo-do-colmo Tibraca limbativentris (Heteroptera: Pentatomidae) em lavoura de arroz irrigado. Cienc Rural. 34:1681-1688.

Nuyttens D, Devarrewaere W, Verbovenb P, Foque D (2013) Pesticide-laden dust emission and drift from treated seeds during seed drilling: a review. Pest Manag Sci. 2013; 69: 564-575.

Pitt JI, Hocking AD (1997) Fungi and food spoilage. 2 ed. London, United Kingdom: Blackie Academic and Professional. $519 \mathrm{pp}$. 
Roberts DW, Stleger RJ (2004) Metarhizium spp., cosmopolitan insect pathogenic fungi: mycological aspects. Adv Appl Microbiol. 54: 1-70.

Rohde C, Alvez LFA, Neves PMOJ, Alves SB., Silva ERL, Almeida JEM (2006) Selectionof Beauveria bassiana (Bals.) Vuill. and Metarhizium anisopliae (Metsch.) Sorok. isolates against Alphitobius diaperinus (Panzer) (Coleoptera: Tenebrionidae). Neotrop Entomol. 35:231240.

Rompelotti FT, Ferreira A, Prando HF, Gritzmacher A, Martins JF, Tcancenco FS. Mattos MLT (2007) Patogenicidade de Metarhizium anisopliae (Metsch.) Sorokin sobre as fases do desenvolvimento de Tibraca limbativentris Stal (Hemiptera: Pentatomidae) em condições de laboratório. Arq Inst Biol. 74:141-148.

Roy HE, Cottrell TE (2008) Forgotten natural enemies: Interactions between coccinellids and insect-parasitic fungi. Eur J Entomol. 105:391-398.

Sandhu SS, Sharma AK, Beniwal V, Goel G, Batra P, Kumar A, Jaglan S, Sharma AK, Malhotra S (2012) MycoBiocontrol of Insect Pests: Factors Involved, Mechanism, and Regulation. J Pathog. 2012, 126819-126829.
Sosa-Gomez DR, Silva JJ (2010) Neotropical brown stink bug (Euschistus heros) resistance to methamidophos in Paraná, Brazil. Pesq Agropec Bras. 45:767-769.

Sung GH, Hywel-Jones NL, Sung JM, Luan-Gsaard JJ, Shresthra B, Spatafora JW (2007) Phylogenetic classification of Cordyceps and the clavicipitaceous fungi. Stud Mycol. 57:1-59.

Tibola CS, Lorini I, Miranda MZ (2009) Boas práticas e sistema APPCC na pós-colheita de trigo. Passo Fundo: Embrapa Trigo, 20 pp.

Xavier LMS, Ávila CJ (2006) Patogenicidade de isolados de Metarhizium anisopliae (Metsch.) Sorokin e de Beauveria bassiana (Bals.) Vuillemin a Scaptocoris carvalhoi Becker (Hemiptera, Cydnidae). Rev Bras Entomol. 50:540-546.

Yip HY, Rath AC, Koen TB (1992) Characterization of Metarhizium anisopliae isolates from Tasmanian pasture soils and their pathogenicity to redheaded cockchafer (Coleoptera: Scarabaeidae: Adoryphorus couloni). Mycol Res. 96:92-96. 